\title{
Molecular Epidemiology of Bovine Babesiosis in Punjab, Pakistan
}

\author{
Asif Masih, Azhar Rafique, Farhat Jabeen \& Shabana Naz
}

\begin{abstract}
Background: Babesiosis is endemic in Pakistan and is one of the most important bovine diseases that causes huge economic losses and high mortality in young animals. This disease is transmitted by a protozoan parasite, which belongs to genus Babesia (Apicomplexa: Piroplasmida: Babesiidae). This disease is very much prevalent in summers followed by rainy season because humid environment is favorable for the growth of these parasites. An epidemiological and molecular study was conducted to unveil the prevalence and associated risk factors of Babesia bigemina (B. bigemina) and Babesia bovis (B. bovis) in selected districts i.e., Faisalabad, Toba Tek Singh and Jhang of Punjab, Pakistan.

Materials, Methods $\&$ Results: A total of $518($ Cattle $=360$, Buffalo $=158)$ blood samples were collected. The samples were analyzed by polymerase chain reaction (PCR) and nested PCR (n-PCR) targeting apocytochrome b-genes $(C Y T b)$. Chi-square test for univariate analysis was used to analyze the data. The overall prevalence in summer based upon microscopic analysis was $20.55 \%$ (37/180) and $13.92 \%$ (11/79) in cattle and buffaloes respectively and in winter was $8.80 \%$ $(16 / 180), 5.06 \%$ (4/79)) in cattle and buffaloes respectively. The samples were further analyzed through conventional PCR (c-PCR) and nested PCR (nPCR). The overall results of conventional PCR in summer showed that 72 cows and buffaloes were infected with babesiosis. The conventional PCR based results of summer showed that prevalence of babesiosis was $29.44 \%$ (53/180) in cows and 24.05\% (19/79) buffaloes. The results of cPCR during the winter season showed that $12.77 \%$ (23/180) and $13.92 \%$ (11/79) buffaloes were positive for babesiosis. The overall results of conventional PCR in winter showed that 34/259 cows and buffaloes were infected with babesiosis. On the other hand, the nested PCR results of summer season showed that the prevalence of babesiosis in cows was 32.22\% (58/180) and 29.11\% (23/79) in buffaloes. In total, 81 cows and buffaloes were infected with babesiosis during summer season. The nPCR results of winter showed that $15 \%$ (27/180) cows and 20.25\% (16/79) buffaloes were infected with babesiosis. In total, 43 cows and buffaloes were infected with babesiosis. The results have shown that sensitivity of n-PCR is more as compared to conventional PCR. This study is the first molecular evidence of B. bigemina and B. bovis and its associated risk factors in Punjab province, Pakistan.

Discussion: Dairy sector in Pakistan is one of the fastest growing sectors. Despite of remarkable growth, dairy industry is facing many problems one of them is tick borne diseases (TBDs). TBDs are more prevalent in tropical and subtropical areas of the world and leads to huge economic losses to dairy industry in terms of decreased milk, meat and wool production. Babesiosis is characterized by increased fever, decreased production, poor quality wool, anemia, hemoglobinuria, paleness of mucous membrane. The risk factors analysis of summer and winter data revealed that, adult animals were more prone to babesiosis (24.00\%) $[P=0.032]$ and $(8.50 \%)[P=0.048]$. In both seasons (summer and winter), females were more infected with babesiosis (20.19\% and 8.17\%) $[P=0.049$ and $P=0.021]$ as compared to males, high prevalence in females was might be due to that females were reared for longer period of time. Babesiosis was more occurred in noncemented floor system (26.01\% and $13.51 \%)[P=0.028$ and $P=0.044]$ in summer and winter, respectively. Disease was found more prevalent in closed housing system in summer and winter $(27.27 \%$ and $10.93 \%)[P=0.043$ and $P=0.034]$ as compared to open housing. Weak animals were more infected with babesiosis $(30.84 \%)[P=0.045]$ and $(12.80 \%)[P$ $=0.042]$ in summer and winter, as compared to healthy ones. The animals with high tick infestations were more suffered with babesia infection (25.49\% and $13.34 \%)[P=0.036$ and $P=0.003]$ in both seasons as compared to less tick burden.
\end{abstract}

Keywords: apocytochrome gene, babesiosis, bovine, nPCR, PCR, season. 


\section{INTRODUCTION}

Bovine babesiosis is one of leading tick-borne infestation facing by dairy industry [25]. This disease is transmitted by a protozoan parasite, which belongs to genus Babesia [3,11-13,23]. There are many $B a$ besia species exists like $B$. bovis, $B$. bigemina and $B$. divergens which cause the clinical babesiosis in bovines $[6,8,10,11,32]$. In general, $B$. bovis is considered to be more pathogenic in bovines followed $B$. bigemina and $B$. divergens. Clinical manifestations of disease include high fever, loss of appetite, anemia, hemoglobinuria and paleness of mucous membrane $[7,9,15,22,31]$.

Blood film examinations under microscope is commonly used for diagnosis of Babesia but this examination is only used for current and active infection where the parasitemia is high but not useful for carrier animals [2,28,32]. Previously, in Pakistan prevalence has been reported was $2.85 \%, 2.80 \% 2.5 \%$ and $9.67 \%$ in in district Lahore, Peshawar, Kasur and Sahiwal, respectively $[33,34]$.

Very few data based upon the molecular diagnosis of bovine babesiosis is available in Pakistan. The prevalence of babesiosis in district Kasur and southern Punjab in Pakistan was reported 33.33\% and $18.75 \%$ respectively [11,34]. PCR and Nested PCR (n-PCR) have been found very sensitive particularly in case of bovine babesiosis (B. bovis and B. bigemina) [7,8,24,27].

The data on diagnosis of babesiosis by two molecular techniques i.e., PCR and n-PCR missing in most parts of the country, keeping in view the fact that the present project was planned to detect the Babesia in carrier animals (cows \& buffaloes) and to differentiate the Babesia species (B. bovis and B. bigemina) by using specie specific primers.

\section{MATERIALS AND METHODS}

\section{Sampling and initial screening}

The present study was carried out in the year of 2019 (summer + winter). For this, a total of 518 blood samples from cows $(n=360)$ and buffaloes $(n=$ 158) were collected in both seasons (summer + winter) from three districts i.e., Faisalabad, Toba Tek Singh and Jhang of Punjab, Pakistan (Figure 1). The samples were randomly collected from healthy animals, initially all the samples were screened via the thin blood smear stained with Giemsa under oil immersion microscope ${ }^{1}$ by using all the necessary procedures and protocol [4]. For the molecular investigations, additionally 3-4 mL of blood in vial ${ }^{2}$ containing EDTA was also collected for DNA extraction. For studying the associated risk factors a questionnaire was designed and filled in each case.

Molecular investigations of Babesia bovis and $\mathrm{B}$. bigemina DNA extraction

The genomic DNA from all the collected blood samples $(n=518)$ were isolated by using raw method i.e., phenol chloroform method by adopting all the protocols [4]. The Genomic DNA of the Babesia pathogens isolated from suspected large ruminants regardless of the ruminant being bovines or buffaloes. The erythrocytes of the animals were first be subjected to a lysis buffer and then proteinase $\mathrm{K}^{3}$ was introduced to the solution at $10 \mathrm{mg} / \mathrm{mL}$ and was allowed for 20 min rest in an incubator at $56^{\circ} \mathrm{C}$ for around $2 \mathrm{~h}$ to allow for the proteinase $\mathrm{K}^{3}$ for all the erythrocyte proteins in the solution to be digested. Then the extraction agent for isolating DNA, Phenol chloroform isoamyl alcohol ${ }^{4}$ was added and the solution was centrifuged at 20000-24000 x $g$ for $15 \mathrm{~min}$. The upper phase - clear solution - was taken in a new Eppendorf 2 tube and the bottom layer was discarded. Ethanol $96 \%$ was added to make the total volume 3 folds (by adding $2.5 \times 96 \%$ ethanol by volume) and then it was allowed to rest in an incubator for $45 \mathrm{~min}$ at $-20^{\circ} \mathrm{C}$ and then it was centrifuged again at 20000-24000 $\mathrm{g}$ for $15 \mathrm{~min}$. This solution washed in $70 \%$ ethanol and the DNA was then be dissolved in TAE buffer ${ }^{3}(10 \mathrm{mM}$ Tris- $\mathrm{HCl} \mathrm{pH} 8$, $0.1 \mathrm{mM}$ EDTA) at $55^{\circ} \mathrm{C}$ after it has been air dried. The sample DNA was stored at $-20^{\circ} \mathrm{C}$ for molecular study.

\section{PCR analysis}

The DNA samples thus obtained from prospectively infected ruminants (B. bovis and B. bigemina) was propagated through PCR using the primers ${ }^{5}$ (Table 1) for Babesia species [23]. These Primers ${ }^{5}$ have been designed based on the sequence derived from flanking part of hyper variable region of 18 sr RNA. According to the protocol described in the literature; $5 \mu \mathrm{L}$ of template (sample) DNA + 1X PCR buffer + 0.1 U TaqPolymerase $+0.5 \mu \mathrm{L}$ of $20 \mathrm{mM}$ P1/P2 (both primers) $+125 \mu \mathrm{M}$ of deoxadenosine triphosphate $+125 \mu \mathrm{M}$ deoxythymidine triphosphate $+125 \mu \mathrm{M}$ deoxycytidine 
triphosphate $+125 \mu \mathrm{M}$ deoxyguanosine triphosphate) $+1.5 \mathrm{mM} \mathrm{MgCl}_{2}$; totaling $25 \mu \mathrm{L}$ was placed in PCR tubes $^{3}$ and loaded into an automatic thermocycler ${ }^{6}$. The thermocycle scheme used was: $5 \mathrm{~min}$ at $95^{\circ} \mathrm{C}$ (to thermally denature DNA double strands into single strand) then 38 cycles of $45 \mathrm{~s}$ at $94^{\circ} \mathrm{C}$ then $45 \mathrm{~s}$ at $56^{\circ} \mathrm{C}$ then 45 $\mathrm{s}$ at $72^{\circ} \mathrm{C}$ and a final cool down phase of $10 \mathrm{~min}$. The PCR product thus received was then be loaded into an agarose gel block made with $100 \mathrm{~mL}$ of $1.5 \%$ agarose $^{3}$ solution and 3-5 $\mu \mathrm{L}$ of ethidium bromide 4 . The product sizes of B. bigemina and B. bovis were 394 bp \& 260 bp through c-PCR [23] (Figures 4 \& 6).

\section{Nested PCR}

The samples were further analyzed through the nested PCR (n-PCR) by adopting following protocols found in the literature, the total volume of the PCR mix was $25 \mu \mathrm{L}$ including $12.5 \mu \mathrm{L}$ master mix ${ }^{3}, 5.5 \mu \mathrm{L}$ of ultrapure water, $10 \mathrm{pM}$ of each primer as depicted in (Table 1 ) and $5 \mu \mathrm{L}$ of the sample DNA template. Primer annealing temperatures was experimentally derived

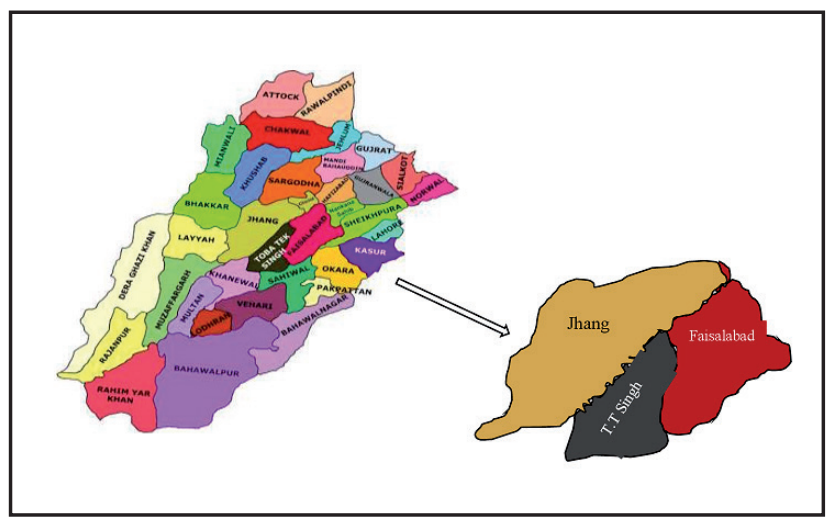

Figure 1. Map of Punjab, Pakistan showing the sampling districts.

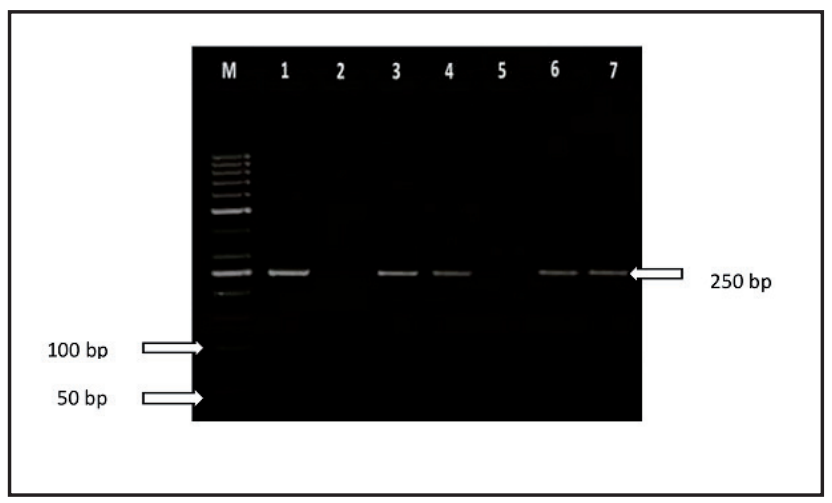

Figure 3. Photograph of sample showing positive results for Babesia bigemina (nPCR). M is DNA ladder (50 bp); 1 is control positive; 2 is control negative; samples 3,4 \& 6,7 are positive for Babesia bigemina while sample 5 is negative. in a Master Cycler Gradient thermocycler ${ }^{6}$. The PCR protocol - $1 \mathrm{~min}$ at $95^{\circ} \mathrm{C}$ initial denaturation; 35 cycles of $1 \mathrm{~min}$ at $95^{\circ} \mathrm{C}$ then $1 \mathrm{~min}$ at $60^{\circ} \mathrm{C}$ annealing then 1 min at $72^{\circ} \mathrm{C}$ extension; and a final extension of $5 \mathrm{~min}$ at $72^{\circ} \mathrm{C}$ - n-PCR step was used the same protocol except at step of annealing which was $69^{\circ} \mathrm{C}$ instead of $60^{\circ} \mathrm{C}$. For B. bigemina specifically, the PCR conditions were squeezed to be $-2 \mathrm{~min}$ at $95^{\circ} \mathrm{C}$ initial denaturation; 40 cycles of $1 \mathrm{~min}$ at $94^{\circ} \mathrm{C}$ then $30 \mathrm{~s}$ at $66^{\circ} \mathrm{C}$ annealing then $1 \mathrm{~min}$ at $72^{\circ} \mathrm{C}$ extension; and a final extension of $5 \mathrm{~min}$ at $72^{\circ} \mathrm{C}$. The product sizes of $\mathrm{B}$. bigemina and B. bovis were 250 bp \& 195 bp through n-PCR [23] (Figures 3 \&5).

\section{Statistical analysis}

The obtained data regarding the prevalence and hypothesized associated risk factors was analyzed through the chi-square analysis for univariate by using the Minitab7 19 for windows. Odd ratio was determined to prove degree of association of risk factors. $P$ value less than 0.05 was considered significant.

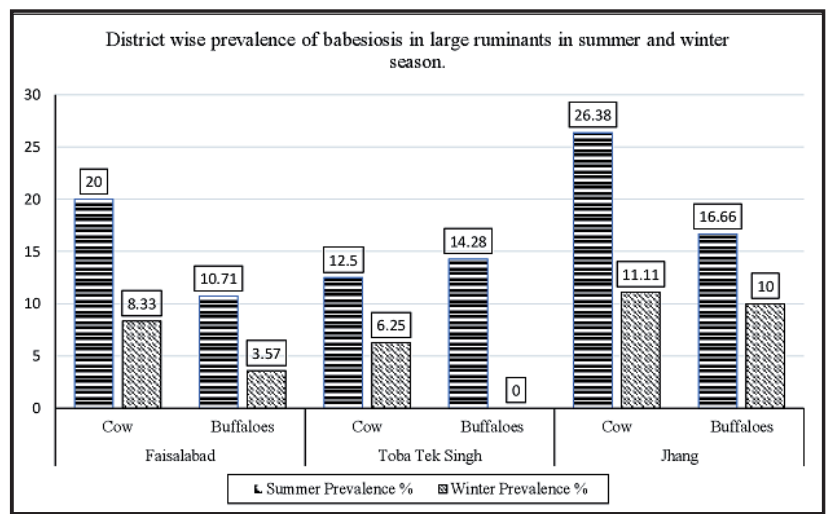

Figure 2. District wise prevalence of babesiosis in large ruminants in summer and winter season.

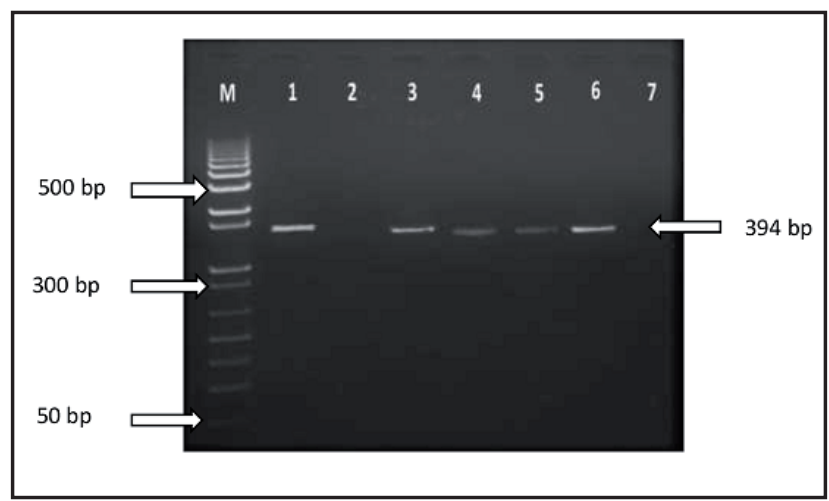

Figure 4. Photograph of sample showing positive results for Babesia bigemina (PCR). $\mathrm{M}$ is DNA ladder (50 bp); 1 is control positive; 2 is control negative; samples $3,4,5 \& 6$ are positive for Babesia bigemina while sample 7 is negative. 


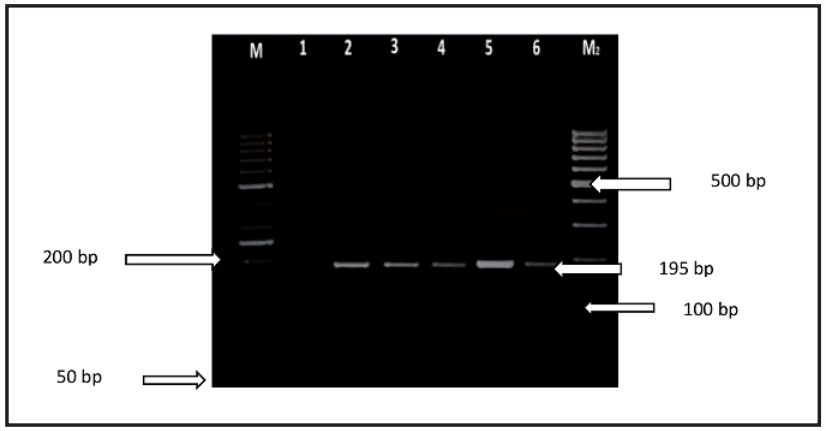

Figure 5. Photograph of sample showing positive results for Babesia bovis (nPCR). M is DNA ladder (50 bp); M2 is ladder (100bp); 1 is control negative; 2 is control positive; samples 3,4, 5 \& 6 are positive for Babesia bovis.

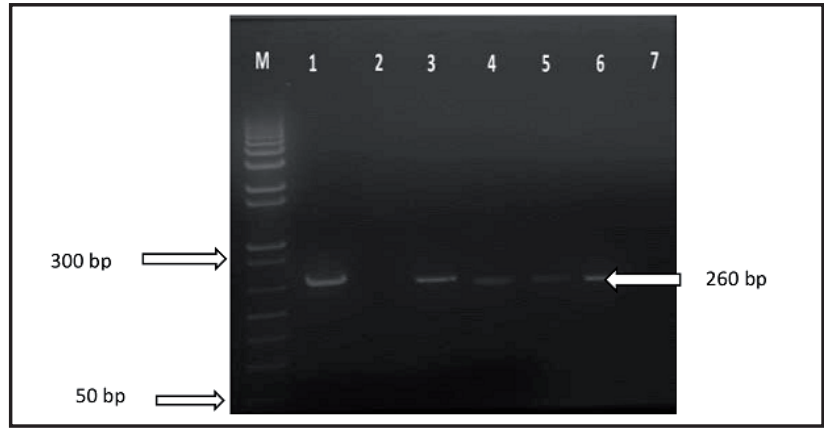

Figure 6. Photograph of sample showing positive results for Babesia bovis (PCR).

Table 1. Primer sets used for Babesia bovis and Babesia bigemina.

\begin{tabular}{|c|c|c|c|c|c|}
\hline Parasite & Assay & Primer & Primer sequence & Size & Reference \\
\hline \multirow{2}{*}{ B. bovis } & \multirow{2}{*}{$\begin{array}{c}\text { PCR } \\
\text { nPCR }\end{array}$} & $\begin{array}{l}\text { Bbo F } \\
\text { Bbo R }\end{array}$ & $\begin{array}{l}\text { TGAACAAAGCAGGTATCATAGG } \\
\text { CCAAGGAGATTGTGATAATTCA }\end{array}$ & $260 \mathrm{bp}$ & \multirow[b]{2}{*}{ [23] } \\
\hline & & $\begin{array}{l}\text { iBbo F } \\
\text { iBbo R }\end{array}$ & $\begin{array}{l}\text { TCCACGATCTGTGATACGTCA } \\
\text { CAAATCCTTTGCAAACTCCAA } \\
\end{array}$ & $195 \mathrm{bp}$ & \\
\hline \multirow{2}{*}{ B. bigemina } & \multirow{2}{*}{$\begin{array}{l}\text { PCR } \\
\text { nPCR }\end{array}$} & $\begin{array}{l}\text { Bbig F } \\
\text { Bbig R }\end{array}$ & $\begin{array}{l}\text { TCCAACACCAAATCCTCCTA } \\
\text { CGTGGGTTTCGTTTTTGTAT }\end{array}$ & 394 bp & \\
\hline & & $\begin{array}{l}\text { iBbig F } \\
\text { iBbig R }\end{array}$ & $\begin{array}{l}\text { AAGAGATACCATATCAGGGAACCA } \\
\text { TTGGGCACTTCGTTATTTCC }\end{array}$ & $250 \mathrm{bp}$ & [23] \\
\hline
\end{tabular}

\section{RESULTS}

Present study was planned to investigate the molecular detection of babesiosis in large ruminants (cows + buffaloes) in both seasons (Summer + Winter), for this purpose a total of 518 blood samples ( $\mathrm{n}=$ $518)$ were collected i.e., cows $(n=360)$ and buffaloes $(\mathrm{n}=158)$ residing in Faisalabad, Toba Tek Singh and Jhang districts of Punjab, Pakistan. First of all, the samples were examined under microscope by making a thin blood smear. The blood smear exposed parasite schizonts as tear drop in pair identified as babesia. In summer overall prevalence based upon the blood film examinations indicated 20.55 (37/180), 13.92\% $(11 / 79)$ in cows and buffaloes, respectively and in winter was 8.88 (16/180), 5.06\% (4/79) in cows and buffaloes, respectively. Furthermore, the prevalence based upon different risk factors i.e., age, sex, feeding, housing, floor system, presence or absence of ticks was determined. Statistical analysis of different risk factors (Table 2) indicated that, increased age, female, noncemented floor, closed housing, weak body condition and heavy infestation of ticks increase the incidence of disease by many folds.
It was also noted that the district wise prevalence of babesiosis was also different in both seasons i.e., in summer the prevalence in cows was 20.00 (12/60), 12.50 (6/48) and 26.38\% (19/72) in Faisalabad, Toba Tek Singh and Jhang, respectively, while in buffalo's prevalence was 10.71 (3/28), 14.28\% (3/21) and $16.66 \%$ (5/30) in Faisalabad, Toba Tek Singh and Jhang respectively. While in winter the prevalence in cows was 8.33 (5/60), 6.25 (3/48) and $11.11 \%(8 / 72)$ in Faisalabad, Toba Tek Singh and Jhang respectively, while in buffalo prevalence was 3.57 (01/28), 0.00 $(0 / 21)$ and $10.00 \%(3 / 30)$ in Faisalabad, Toba Tek Singh and Jhang, respectively (Table 3) (Figure 2).

The samples were further analyzed through the conventional PCR (c-PCR) and nested PCR (nPCR). The overall results of conventional PCR in summer showed that 72 cows and buffaloes were infected with babesiosis. The conventional PCR based results of summer showed that $29.44 \%$ (53/180) cows and 24.05\% (19/79) buffaloes were infected with babesiosis. Among the 53 infected cows 29 were positive for Babesia bigemina while the remaining 24 cows were infected with Babesia bovis. Similarly, 10 infected buffaloes were positive for Babesia bigemina and 
9 were infected with Babesia bovis. The results of cPCR during the winter season revealed that $12.77 \%(23 / 180)$ cows were found positive for babesiosis. Among these, 16 cows $B$. bigemina was present while in remaining 7 cows B. bovis was present. Similarly, 13.92\% (11/79) buffaloes were infected with babesiosis. Among them, 7 were positive for B. bigemina and 4 were positive for $B$. bovis. The overall results of conventional PCR in winter showed that 34/259 cows and buffaloes were infected with babesiosis (Table 4). On the other hand, the nested PCR results of summer season showed that the prevalence of babesiosis in cows was $32.22 \%(58 / 180)$ and $29.11 \%$ (23/79) in buffaloes. Among these infected cows, 34 were $B$. bigemina positive while remaining 24 were positive for $B$. bovis. The
16 buffaloes were positive for Babesia bigemina and 7 were positive for Babesia bovis. In total, 81 cows and buffaloes were infected with babesiosis during summer season. The nPCR results of winter showed that $15 \%$ (27/180) cows and $20.25 \%$ (16/79) buffaloes were infected with babesiosis. Among the infected cows, 17 were positive for B. bigemina and 10 were positive for $B$. bovis. Similarly, 9 buffaloes were positive for $B$. bigemina while 7 were positive for B. bovis. So, 43 cows and buffaloes were infected with babesiosis in winter (Table 5). The results have shown that sensitivity of n-PCR is more as compared to conventional PCR. The product sizes of $B$. bigemina were $394 \mathrm{bp} \& 250$ bp and of B. bovis 195 bp \& 260 bp through c-PCR and n-PCR (Figures 3,4,5 \& 6).

Table 2. Prevalence of babesiosis in bovine in relation to different risk factors in both seasons (Summer \& Winter) based upon microscopy.

\begin{tabular}{|c|c|c|c|c|c|c|c|}
\hline \multicolumn{8}{|c|}{ Summer } \\
\hline \multirow{2}{*}{ Risk factor } & \multirow{2}{*}{ Variable } & \multirow{2}{*}{ Prevalence \% } & \multirow{2}{*}{ Chi-square } & \multirow{2}{*}{ Odds Ratio } & \multicolumn{2}{|c|}{$95 \% \mathrm{CI}$} & \multirow{2}{*}{$P$-value } \\
\hline & & & & & Lower & Upper & \\
\hline \multirow{2}{*}{ Age } & Young & $12 / 109(11.00)$ & \multirow{2}{*}{23.22} & \multirow{2}{*}{2.42} & \multirow{2}{*}{$(1.21$} & \multirow{2}{*}{ 2.98) } & \multirow{2}{*}{0.032} \\
\hline & Adult & $36 / 150(24.00)$ & & & & & \\
\hline \multirow{2}{*}{ Sex } & Female & $42 / 208(20.19)$ & \multirow{2}{*}{12.33} & \multirow{2}{*}{1.59} & \multirow{2}{*}{$(1.31$} & \multirow{2}{*}{ 1.67) } & \multirow{2}{*}{0.049} \\
\hline & male & 6/51 (11.76) & & & & & \\
\hline \multirow{2}{*}{ Feeding system } & ground & $33 / 148(22.29)$ & \multirow{2}{*}{14.75} & \multirow{2}{*}{1.96} & \multirow{2}{*}{$(1.56$} & \multirow{2}{*}{ 2.32) } & 0,048 \\
\hline & trough & 15/111(13.51) & & & & & 0.040 \\
\hline Floor & cemented & $16 / 136(11.76)$ & 2933 & 294 & (2) 31 & $308)$ & 0.028 \\
\hline ГI001 & Non-cemented & $32 / 123(26.01)$ & 29.55 & 2.94 & $(2.51$ & $5.00)$ & 0.020 \\
\hline Ноusing & open & $18 / 149(12.08)$ & 1743 & 072 & $(041$ & $008)$ & 0,043 \\
\hline nousmg & closed & $30 / 110(27.27)$ & 17.45 & 0.12 & $(0.41$ & $0.90)$ & 0.045 \\
\hline Herd & $>20$ animals & $34 / 154(22.07)$ & 1844 & 121 & $(0.43$ & (78) & 0.048 \\
\hline 17cru & $<20$ animals & $14 / 105(13.33)$ & $10.4+4$ & 1.21 & (0.4) & $0.10)$ & $0.0+0$ \\
\hline Body condition & good & $15 / 152(9.86)$ & 28.44 & 064 & $(101$ & 143) & 0.045 \\
\hline & poor & $33 / 107(30.84)$ & & & & 1.45) & \\
\hline Ticks & present & $42 / 153(27.45)$ & 1894 & 149 & (1) 16 & 167) & 0036 \\
\hline 11CKS & absent & 06/106 (5.66) & 18.94 & 1.49 & $(1.10$ & $1.0 /)$ & 0.030 \\
\hline Dog association & present & $35 / 150(23.33)$ & 1942 & 100 & (1 34 & 212) & 0033 \\
\hline Dog association & absent & 13/109 (11.92) & 19.42 & 1.90 & $(1.34$ & $2.12)$ & 0.053 \\
\hline & & & Vinter & & & & \\
\hline Age & Young & $3 / 72(4.16)$ & 1903 & 159 & $(101$ & 122) & 0,048 \\
\hline Age & Adult & $17 / 187(9.09)$ & 19.05 & 1.39 & $(1.01$ & $1.22)$ & 0.040 \\
\hline Sex & Female & $17 / 208(8.17)$ & 3082 & 210 & (190 90 & $223)$ & 0021 \\
\hline & male & $3 / 51(5.88)$ & & 2.10 & (1.90 & $2.25)$ & 0.021 \\
\hline Feeding system & ground & $16 / 126(12.69)$ & 17,43 & 177 & (1 42 & 189) & 0043 \\
\hline recumg system & trough & 4/133 (3.00) & 17.45 & 1.17 & $(1.42$ & $1.07)$ & $0.0+3$ \\
\hline Floor & cemented & $5 / 148(3.37)$ & 2105 & 1.40 & (120 & $156)$ & 0.044 \\
\hline & Non-cemented & $15 / 111(13.51)$ & & & & $1.50)$ & 0.044 \\
\hline Housing & open & $6 / 131(4.56)$ & 2433 & 201 & 178 & $210)$ & 0034 \\
\hline Housing & closed & $14 / 128(10.93)$ & 24.53 & 2.01 & $(1.10$ & $2.10)$ & 0.054 \\
\hline Herd & $>20$ animals & $14 / 150(9.33)$ & 1465 & 0.94 & $(0.45$ & 122) & 0.044 \\
\hline & $<20$ animals & $6 / 109(5.50)$ & 14.05 & & & & 0.044 \\
\hline Body condition & good & 4/134 (2.98) & 2322 & 120 & (1) 11 & 134) & 0042 \\
\hline Douy concition & poor & $6 / 125(12.80)$ & 25.22 & 1.20 & $(1.11$ & $1.54)$ & 0.042 \\
\hline Ticks & present & $18 / 135(13.34)$ & 3933 & 230 & (2) 21 & $245)$ & 0.003 \\
\hline $110 \mathrm{AS}$ & absent & 2/124 (1.61) & (59.53 & 2.00 & $(2.21$ & $2.45)$ & 0.003 \\
\hline Dog association & present & $14 / 139(10.07)$ & 2422 & 1.45 & (1) 15 & 98) & 0025 \\
\hline & absent & $6 / 120(5.00)$ & 24.22 & $1.4 J$ & $(1.1)$ & $1.90)$ & $0.02 J$ \\
\hline
\end{tabular}

$P \leq 0.05=$ Significant; $P \geq 0.05=$ Non- Significant; C.I $=95 \%$. 
A. Masih, A. Rafique, F. Jabeen \& S. Naz. 2021. Molecular Epidemiology of Bovine Babesiosis in Punjab, Pakistan.

Table 3. District wise prevalence of babesiosis in small ruminants in summer and winter season based upon microscopy.

\begin{tabular}{|c|c|c|c|c|c|c|c|}
\hline \multirow{3}{*}{ District } & \multirow{3}{*}{ Variable } & \multirow{3}{*}{ Prevalence $(\%)$} & \multicolumn{4}{|l|}{ Summer } & \multirow{3}{*}{$P$-Value } \\
\hline & & & \multirow{2}{*}{ Chi-Square } & \multirow{2}{*}{ Odds Ratio } & \multicolumn{2}{|c|}{$95 \%$ C. I } & \\
\hline & & & & & Lower & Upper & \\
\hline \multirow{2}{*}{ Faisalabad } & Cow & $12 / 60(20.00)$ & \multirow{2}{*}{13.32} & \multirow{2}{*}{0.78} & \multirow{2}{*}{$(0.45$} & \multirow{2}{*}{$0.97)$} & \multirow{2}{*}{0.043} \\
\hline & Buffalo & $3 / 28(10.71)$ & & & & & \\
\hline \multirow{2}{*}{ Toba Tek Singh } & Cow & $6 / 48(12.50)$ & \multirow{2}{*}{18.95} & \multirow{2}{*}{0.93} & \multirow{2}{*}{$(0.35$} & \multirow{2}{*}{$1.15)$} & \multirow{2}{*}{0.049} \\
\hline & Buffalo & $3 / 21(14.28)$ & & & & & \\
\hline \multirow{2}{*}{ Jhang } & Cow & 19/72 (26.38) & \multirow{2}{*}{21.74} & \multirow{2}{*}{1.49} & \multirow{2}{*}{$(1.32$} & \multirow{2}{*}{$1.54)$} & \multirow{2}{*}{0.039} \\
\hline & Buffalo & $5 / 30(16.66)$ & & & & & \\
\hline \multirow{2}{*}{ Total } & Cow & $37 / 180(20.55)$ & \multirow{2}{*}{20.42} & \multirow{2}{*}{1.78} & \multirow{2}{*}{$(1.47$} & \multirow{2}{*}{$1.90)$} & \multirow{2}{*}{0.020} \\
\hline & Buffalo & $11 / 79(13.92)$ & & & & & \\
\hline \multicolumn{8}{|c|}{ Winter } \\
\hline \multirow{2}{*}{ Faisalabad } & Cow & $5 / 60(8.33)$ & \multirow{2}{*}{23.52} & 150 & $(148$ & $188)$ & 0040 \\
\hline & Buffalo & $1 / 29(3.57)$ & & 1.59 & $(1.48$ & $1.88)$ & 0.040 \\
\hline Toha Tak Sinoh & Cow & $3 / 48(6.25)$ & 1042 & 084 & $(0.47$ & $090)$ & 0038 \\
\hline IoDa Iек singn & Buffalo & $0 / 21(0.00)$ & 19.42 & 0.84 & $(0.4)$ & $0.90)$ & 0.038 \\
\hline Jhong & Cow & $8 / 72(11.11)$ & 2003 & 130 & $(144$ & $1.15)$ & 0040 \\
\hline Jnang & Buffalo & $3 / 30(10.00)$ & 20.03 & 1.50 & $(1.14$ & $1.45)$ & 0.049 \\
\hline Totol & Cow & $16 / 180(8.88)$ & 1632 & 064 & $(0.34$ & $080)$ & 0035 \\
\hline & Buffalo & $4 / 79(5.06)$ & & & & & \\
\hline
\end{tabular}

$P \leq 0.05=$ Significant $P \geq 0.05=$ Non- Significant; C.I $=95 \%$.

Table 4. Positive samples for conventional PCR in summer season and winter season.

\begin{tabular}{|c|c|c|c|c|c|c|c|}
\hline \multicolumn{8}{|c|}{ Summer Season } \\
\hline \multirow{2}{*}{ Species } & \multirow{2}{*}{ Total } & \multicolumn{2}{|c|}{ Babesia genus } & \multicolumn{2}{|c|}{ B. bigemina } & \multicolumn{2}{|c|}{ B. bovis } \\
\hline & & Positive & Percentage & Positive & Percentage & Positive & Percentage \\
\hline Cow & 180 & 53 & 29.44 & 29 & 16.11 & 24 & 13.34 \\
\hline Buffalo & 79 & 19 & 24.05 & 10 & 12.65 & 09 & 11.39 \\
\hline Total & 259 & 72 & 27.79 & 39 & 15.05 & 33 & 12.74 \\
\hline \multicolumn{8}{|c|}{ Winter Season } \\
\hline \multirow{2}{*}{ Species } & \multirow{2}{*}{ Total } & \multicolumn{2}{|c|}{ Babesia genus } & \multicolumn{2}{|c|}{ B. bigemina } & \multicolumn{2}{|c|}{ B. bovis } \\
\hline & & Positive & Percentage & Positive & Percentage & Positive & Percentage \\
\hline Cow & 180 & 23 & 12.77 & 16 & 8.89 & 07 & 3.89 \\
\hline Buffalo & 79 & 11 & 13.92 & 07 & 8.86 & 04 & 5.06 \\
\hline Total & 259 & 34 & 13.12 & 23 & 8.89 & 11 & 4.24 \\
\hline
\end{tabular}

Table 5. Positive samples for nested PCR in summer season and winter season.

\begin{tabular}{|c|c|c|c|c|c|c|c|}
\hline \multicolumn{8}{|c|}{ Summer Season } \\
\hline \multirow{2}{*}{ Species } & \multirow{2}{*}{ Total } & \multicolumn{2}{|c|}{ Babesia genus } & \multicolumn{2}{|c|}{ B. bigemina } & \multicolumn{2}{|c|}{ B. bovis } \\
\hline & & Positive & Percentage & Positive & Percentage & Positive & Percentage \\
\hline Cow & 180 & 58 & 32.22 & 34 & 18.89 & 24 & 13.34 \\
\hline Buffalo & 79 & 23 & 29.11 & 16 & 20.25 & 07 & 8.86 \\
\hline Total & 259 & 81 & 31.27 & 50 & 19.30 & 31 & 11.97 \\
\hline \multicolumn{8}{|c|}{ Winter Season } \\
\hline \multirow{2}{*}{ Species } & \multirow{2}{*}{ Total } & \multicolumn{2}{|c|}{ Babesia genus } & \multicolumn{2}{|c|}{ B. bigemina } & \multicolumn{2}{|c|}{ B. bovis } \\
\hline & & Positive & Percentage & Positive & Percentage & Positive & Percentage \\
\hline Cow & 180 & 27 & 15.00 & 17 & 9.44 & 10 & 5.56 \\
\hline Buffalo & 79 & 16 & 20.25 & 09 & 11.39 & 07 & 8.86 \\
\hline Total & 259 & 43 & 16.60 & 26 & 10.03 & 17 & 6.56 \\
\hline
\end{tabular}




\section{DISCUSSION}

Dairy sector in Pakistan is one of the fastest growing sectors. In national GDP livestock has a shear of about $11.6 \%$ along with that $58.9 \%$ shear is included in agriculture values in 2017-2018. It is observed that $70 \%$ of rural economy is directly or indirectly dependent upon livestock i.e., by selling the milk and meat. Rearing of cattle and buffalo has much importance in rural areas especially for nonagricultural poor families they mostly use horses and donkeys for carrying fodder for their animals $[17,26]$.

Despite of remarkable growth in livestock sector, dairy industry is facing many problems one of them is tick borne diseases (TBDs) [29]. TBDs cause severe losses to animals particularly large ruminants (cattle and buffaloes). TBDs are more prevalent in tropical and subtropical areas of the world and leads to huge economic losses to dairy industry in terms of decreased milk, meat and wool production [14]. Some of diseases are zoonotic in origin and leads to problem in human also. Babesiosis is one of them, which is characterized by increased fever, decreased production, poor quality wool, anemia, hemoglobinuria, paleness of mucous membrane [20,21]. Sometime nervous signs are noted as result of circulation of infected erythrocytes in cerebral blood vessels and birth of weak offspring. Cattle and Buffaloes are more prone to babesiosis and have been reported as endemic in different areas of Pakistan by various studies at different times [16].

Previously this disease was diagnosed microscopically by making a thin blood smear stained with Giemsa and study under the microscope, but this examination is only used for current and active infection where the parasitemia is high but not useful for carrier animals, also it is very difficult to detect $B$. bovis in blood samples. Animals with chronic infection of Babesia is difficult to detect because of low number of parasites in blood. Indirect Fluorescent Antibody Test (IFAT) is another serological technique used for the detection of antibodies produced by babesia species (B. bovis and B. bigemina) due to cross reactivity this assay is also not very much useful to differentiate the species [19]. So, we need assays, which are equally important for both current and active infection as well as for carrier animals.

Therefore, the current study was conducted to examine Babesia (B. bovis and B. bigemina) in naturally infected cattle and buffalos' herds of Faisalabad,
Toba Tek Singh and Jhang districts of Punjab, Pakistan through molecular diagnostic techniques i.e., PCR and n-PCR.

In current study, the overall prevalence in summer through microscopic analysis was $20.55 \%$ $(37 / 180)$ in cows and $13.92 \%(11 / 79)$ in buffaloes respectively and in winter was $8.80 \%(16 / 180)$, $5.06 \%$ (4/79) in cows and buffaloes respectively. The samples were further analyzed through the conventional PCR (c-PCR) and nested PCR (nPCR). The overall results of conventional PCR in summer showed that 72 cows and buffaloes were infected with babesiosis. The conventional PCR based results of summer showed that prevalence of babesiosis was $29.44 \%$ (53/180) in cows and $24.05 \%$ (19/79) buffaloes. The 29 cows and 10 buffaloes were positive for Babesia bigemina while the remaining 24 cows and 9 buffaloes were infected with Babesia bovis. The results of cPCR during the winter season revealed that $12.77 \%$ (23/180) and $13.92 \%$ (11/79) buffaloes were infected with babesiosis. Among these, 16 cows and 7 buffaloes were infected with $B$. bigemina while in remaining 7 cows and 4 buffaloes $B$. bovis was present. The conventional PCR results of winter showed that 34/259 cows and buffaloes were infected with babesiosis. On the other hand, the nested PCR results of summer season showed that the prevalence of babesiosis in cows was $32.22 \%(58 / 180)$ and $29.11 \%$ (23/79) in buffaloes. Among these infected bovines, 34 cows and 16 buffaloes were $B$. bigemina positive while remaining 24 cows and 7 buffaloes were positive for B. bovis. In total, 81 cows and buffaloes were infected with babesiosis during summer season. The nPCR results of winter showed that $15 \%(27 / 180)$ cows and $20.25 \%$ (16/79) buffaloes were infected with babesiosis. Among the infected animals, 17 cows and 9 buffaloes were positive for $B$. bigemina and 10 cows and 7 buffaloes were positive for B. bovis. In total, 43 cows and buffaloes were infected with babesiosis. The results have shown that sensitivity of n-PCR is more as compared to conventional PCR, Similar findings have been reported in southern Punjab, Pakistan [1,34]. According to him 50\% samples were positive through molecular techniques i.e., PCR and $3 \%$ samples were detected positive via microscopic analysis. Similar results have published and reported that $18 \%$ blood samples were positive through PCR as compared to microscopic 3\% [23]. 
Furthermore, the of risk factors analysis of both seasons (summer and winter) revealed that, adult animals were more prone to babesiosis $(24.00 \%)[P=$ $0.032]$ in summer and $(8.50 \%)[P=0.048]$ in winter as compared to young ones, because the adult animals are active grazers and when they go out for grazing, they are more at risk to ticks secondly immunity decreases with increase in age [18]. Females were more infected with babesiosis in both seasons (20.19\% and $8.17 \%)$ $[P=0.049$ and $P=0.021]$ as compared to males, high prevalence in females was might be due to the fact that females were reared for longer period of time, and female are more prone to physiological stress as compared to male [3]. During this study it was also revealed that non-cemented floor system caused the occurrence of disease in both seasons $(26.01 \%$ and $13.51 \%)[P=0.028$ and $P=0.044]$ as compared to cemented floor system. High occurrence of disease was associated with non-cemented floor system, because in non-cemented floor system there is no proper drainage system, cleanliness of shed along with some cracks in the floor which harbor the parasites that why the eggs of ticks were not properly removed that leads to the incidence of babesiosis in animals [30]. Disease was more prevalent in closed housing system in summer and winter $(27.27 \%$ and $10.93 \%)[P=0.043$ and $P=$ $0.034]$ as compared to open housing this finding was in accordance with this is because of zoonotic nature of disease and disease was more frequent in intensive farming and weak animals were more infected with babesiosis $(30.84 \%)[P=0.045]$ in summer and $(12.80 \%)$ $[P=0.042]$ in winter, as healthy ones [5]. It was also noted that animals with high tick infestations were more suffered with Babesia infection $(25.49 \%$ and $13.34 \%)[P=0.036$ and $P=0.003]$ in both seasons as compared to less tick burden [33]. It was also revealed from present study that feeding system also a major cause of spread of this disease the animals which fed on ground were prone to babesiosis during the summer and winter season $(22.29 \%$ and $11.11 \%)[P=0.048$ and $P=0.043$ ] [34]. The dog association near herds also caused the transmission of disease in both seasons as ticks were present on dogs $(19.42 \%$ and $24.22 \%)[P$ $=0.033$ and $P=0.025]$ and ticks act as an intermediate host [34]. The larger herd size of animals was a major risk factor in the spread of babesiosis $(22.07 \%)[P=$ $0.043]$ in summer and $(9.33 \%)[P=0.044]$ in winter $[11,15]$.

\section{CONCLUSIONS}

Babesiosis is much prevalent in our cattle and buffalos' herds that leads to huge economic losses in terms of poor growth rate, poor quality wool and increased treatment cost after disease outbreak. Commonly smear method is used for detection of blood parasite i.e. Babesia, this is not useful for detection of carrier animals or very low parasitemia. Therefore, current study was conducted to investigate the babesiosis in bovine species in Faisalabad Division. PCR for the detection of Babesia bovis is specific and sensitive. The test is suitable for tracing carrier animal and provide a qualitative and validated measure that is useful in epidemiological surveys, follow ups for drug treatment and ticks control programs in endemic areas to enhance the livestock productivity.

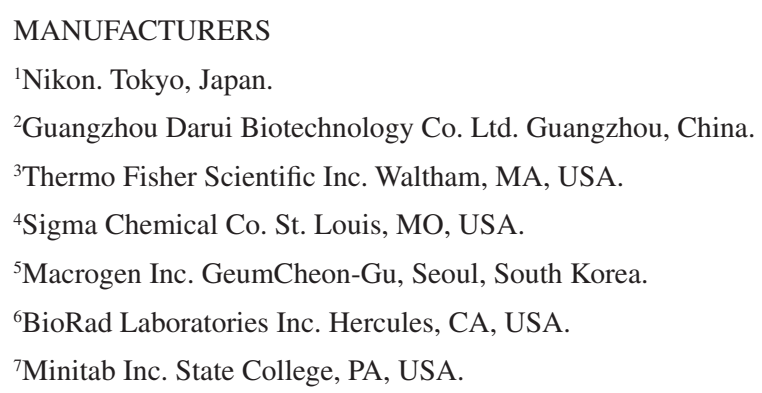

Declaration of interest. The authors report no conflicts of interest. The authors alone are responsible for the content and writing of the paper.

\section{REFERENCES}

1 AbouLaila M., Yokoyama N. \& Igarashi I. 2010. Development and evaluation of a nested PCR based on spherical body protein 2 gene for the diagnosis of Babesia bovis infection. Veterinary Parasitology. 169: 45-50.

2 Afridi Z.K. \& Ahmad I. 2005. Incidence of anaplasmosis, babesiosis and theileriosis in dairy cattle in Peshawar [Pakistan]. Sarhad Journal of Agriculture. 21: 311-316.

3 Alim M.A., Das S. \& Roy K. 2012. Prevalence of hemoprotozoan diseases in cattle population of Chittagong division, Bangladesh. Pakistan Veterinary Journal. 32: 221-4.

4 Almeria S., Castella`J., Ferrer D., Ortunõ A., Estrada-Penã A. \& Gutierrez J.F. 2001. Bovine piroplasms in minorca (Balearic Islands Spain): a comparison of PCR-based and light microscopy detection. Veterinary Parasitology. 99: 249-259. 
5 Amorim L.S., Wenceslau A.A., Carvalho F.S., Carneiro P.L.S. \& Albuquerque G.R. 2014. Bovine babesiosis and anaplasmosis complex: diagnosis and evaluation of the risk factors from Bahia, Brazil. Revista Brasileira de Parasitologia Veterinária. 23(3):328-336.

6 Bawm S., Htun L.L., Maw N.N., Ngwe T., Tosa Y., Kon T., Kaneko C., Nakao R., Sakurai T. \& Kato H. 2016. Molecular survey of Babesia infections in cattle from different areas of Myanmar. Ticks and Tick-Borne Diseases. 7: 204-207.

7 Bhat S.A., Singh H., Singh N.K. \& Rath S.S. 2015. Molecular detection of Babesia bigemina infection in apparently healthy cattle of central plain zone of Punjab. Journal of Parasitology and Diseases. 39: 649-653.

8 Calder J.A.M., Reddy G.R., Chieves L.P., Courtney C.H., Littell R., Livengood J.R., Norval R.A.I., Smith C. \& Dame J.B. 1996. Monitoring Babesia bovis infections in cattle by using PCR-based tests. Journal of Clinical Microbiology.153: 225-230.

9 Chaudhry Z., Suleman M., Younus M. \& Aslim A. 2010. Molecular detection of Babesia bigemina and Babesia bovis in crossbred carrier cattle through PCR. Pakistan Journal of Zoology. 42: 201-204.

10 Durani A.Z. \& Kamal N. 2008. Identification of ticks and detection of blood protozoa in Friesian cattle by PCR and estimation of blood parameters in district Kasur, Pakistan. Tropical Animal Health Production. 40: 441-447.

11 Farooqi S.H., Ijaz M., Rashid M.I., Aqib A.I., Ahmad Z., Saleem M.H., Hussain K., Islam S., Naeem H. \& Khan A. 2017. Molecular epidemiology of Babesia bovis in bovine of Khyber Pakhtunkhwa, Pakistan. Pakistan Veterinary Journal. 37(3): 275-280.

12 Friedhoff K.T. 1994. Transmission of babesia. In: M. Ristic (Ed). Transmission of Babesiosis of Domestic Animals and Man. Boca Raton: CRC press, pp.23-52.

13 Hadani A., Guglielmone A., Gonzales R.L., Bermudez A., Mangold A. \& Barnett S.F. 1982. Use of cerebellar brain smears in the diagnosis of babesiosis (Babesia bovis) in cattle. Tropical Animal Health Production. 14: 242-246.

14 Jirapattharasate C., Moumouni P.F.A., Cao S., Iguchi A., Liu M., Wang G. \& Sungpradit S. 2017. Molecular detection and genetic diversity of bovine Babesia spp., Theileria orientalis, and Anaplasma marginale in beef cattle in Thailand. Parasitology research. 116: 751-762.

15 Khan M., Zahoor A., Jahangir M. \& Mirza M.A. 2004. Prevalence of blood parasites in cattle and buffaloes. Pakistan Veterinary Journal. 24: 193-195.

16 Laha R., Das M. \& Sen A. 2015. Morphology, epidemiology, and phylogeny of Babesia: An overview. Tropical Parasitology. 5: 94-100.

17 Moretti A., Mangili V. \& Salvatori R. 2010. Prevalence and diagnosis of Babesia and Theileria infections in horses in Italy: A preliminary study. The Veterinary Journal. 184: 346-50.

18 Niazi N., Khan M., Avais M. \& Khan J. 2008. Study on Babesiosis in calves at livestock experimental Station Qadirabad and adjacent areas, Sahiwal (Pakistan). Pakistan Journal of Agricultural Sciences. 45: 209-211.

19 O.I.E. 2005. Manual of Standard Tests and Vaccines. Office International des Epizooites, World Organization for Animal Health, Chap. 2.3.8. www.oie.int.

20 Ojeda J., Orozco L. \& Flores R. 2010. Validation of an attenuated live vaccine against babesiosis in native cattle in an endemic area. Transboundary and Emerging Diseases. 57: 84-86.

21 Pupin R.C., Guizelini C., Lemos R. A. A., Martins T.B., Almeida B.F., Borges D.G. L. \& Gomes D.C. 2019. Retrospective study of epidemiological, clinical and pathological findings of bovine babesiosis in Mato Grosso do Sul, Brazil (1995-2017). Ticks and tick-borne diseases. 10(1): 36-42.

22 Rashid A., Khan J. \& Khan M. 2010. Prevalence and chemotherapy of babesiosis among Lohi sheep in the Livestock Experiment Station, Qadirabad, Pakistan. The Journal of Venomous Animals and Toxins including Tropical Diseases. 16: 587-591.

23 Salas D.R., Mira A., Mosqueda J., Vazquez Z. G., Ruiz M. H., Vela N.A.O., Leon A. A. P., Chistensen M. F. \& Schnittger L. 2016. Molecular and serological detection of Babesia bovis and Babesia bigemina infection in bovines and water buffaloes raised jointly in an endemic field. Veterinary Parasitology. 217: 101-107.

24 Salem G.H., Liu X., Johnsrude J. D., Dame J.B. \& Roman G.R. 1999. Development and evaluation of an extra chromosomal DNA-based PCR test for diagnosing bovine babesiosis. Molecular Cellular Probes. 3: 107-113.

25 Savic S., Vidic B. \& Grgic Z. 2015. Emerging vector-borne diseases- incidence through vectors. Emerging zoonoses: eco-epidemiology, involved mechanisms and public health implications. Frontiers in Public Health. 9-12. doi. org/10.3389/fpubh.2015.00157 
26 Shahzad W., Haider N., Mansur-ud-Din A., Munir R., Saghar M.S., Mushtaq M.H. \& Mehmood F. 2013. Prevalence and molecular diagnosis of Babesia ovis and Theileria ovis in Lohi sheep at livestock experiment station (LES), Bahadurnagar, Okara, Pakistan. Iranian Journal of Parasitology. 8: 570-87.

27 Shams S., Ayaz S. \& Ali I. 2013. Sensitivity and specificity of PCR and microscopy in detection of Babesiosis in domesticated cattle of Khyber Pakhtunkhwa, Pakistan. International. Journal of Advanced Research and Technology. 2(5): 37-41.

28 Shang B., Sambono J.L., Morgan J.A.T., Venus B., Rolls P. \& Lew-Tabor A.E. 2016. An evaluation of quantitative PCR assays (TaqMan and SYBR Green) for the detection of Babesia bigemina and Babesia bovis, and a novel fluorescent-ITS1-PCR capillary electrophoresis method for genotyping B. bovis isolates. Veterinary Science. 3: 23-38.

29 Souza A.L., Arias W.A., Santos C.F., Souza C.P.L. \& Albuquerque R.G. 2014. Bovine babesiosis and anaplasmosis complex: Diagnosis and evaluation of the risk factors from Bahia, Brazil. Brazilian Journal of Veterinary Parasitology. 23: 328-336.

30 Suarez C.E., Bishop R.P., Alzan H.F., Poole W.A. \& Cooke B.M. 2017. Advances in the application of genetic manipulation methods to apicomplexan parasites. International Journal for Parasitology. 47: 701-10.

31 Terkawi M.A., Huyen N.X., Shinuo C., Inpankaew T., Maklon K., Aboulaila M., Ueno A., Goo Y.K., Yokoyama N. \& Jittapalapong S. 2011. Molecular and serological prevalence of Babesia bovis and Babesia bigemina in water buffaloes in the northeast region of Thailand. Veterinary Parasitology. 178: 201-207.

32 Wagner G., Cruz D., Holman P., Waghela S., Perrone J., Shompole S. \& Rurangirwa F. 1992. Non-immunologic methods of diagnosis of babesiosis. Memórias do Instituto Oswaldo Cruz. 87: 193-199.

33 Zahid I., Latif M. \& Baloch K. 2005. Incidence and treatment of theileriasis and babesiosis. Pakistan Veterinary Journal. 25: 137-139.

34 Zulfiqar S., Shahnawaz S., Ali M., Bhutta A.M., Iqbal S., Hayat S. \& Iqbal F. 2013. Detection of Babesia bovis in blood samples and its effect on the hematological and serum biochemical profile in large ruminants from Southern Punjab. Asian Pacific Journal of tropical Biomedicine. 2: 104-108. 